\title{
SEMANTIC MAPPING STRATEGY ON STUDENTS' VOCABULARY LEARNING RESULT
}

\author{
Reza ${ }^{1}$, \\ *Universitas Islam As-Syafi'iyah, Jl. Jatiwaringin Raya no 12 PondokGede, Jakarta Timur, \\ Indonesia, Email: rezafkip@gmail.com
}

\author{
Azizah ${ }^{2}$, \\ **Universitas Islam As-Syafi 'iyah, Jl. Jatiwaringin Raya no 12 PondokGede, Jakarta Timur, \\ Indonesia, Email: azizahhamdih@gmail.com
}

\begin{abstract}
This research entitled "The Effect of Semantic Mapping Strategy on Students' Vocabulary Learning Resultat the Grade Ten of SMK Pusaka 1 in Academic Year of 2017/2018" principally aims to investigate whether or not Semantic Mapping Strategy significantly affects on Students' Vocabulary Learning Result. The research samples were taken using cluster random sampling, with the total number of samples being 72 students. The location of this research was SMKPusaka 1 Jakarta. The research methodology adopted was true experimental method, with the research design being randomized post-test only control group design. To collect the data, the students were given objective test, numbering 30 items. The research data were analyzed descriptively and inferentially. The findings indicated that there was significant difference of post-test score between the students who received Semantic Mapping Strategy and students who did not receive Semantic Mapping Strategy. It can be seen from the data analysis using ANOVA that showed $\mathrm{F}_{\text {observed }}(7.801)$ is higher than the critical value of $F_{\text {table }}$ (at the significant level of 0.05 and $\mathrm{df}=1 / 70$ ), namely 3.96. It means that Semantic Mapping Strategy has significant effect on Students' Vocabulary Learning Result.
\end{abstract}

The key words: Semantic Mapping Strategy, Vocabulary Learning Result, Vocabulary

\section{Introduction}

English is one of the best languages used for communication by people around the world, because English has been a global language communication in this era. It means that English should be learnt. English is taught in Indonesia as a foreign language. Besides that, English is one of the compulsory subjects which will be examined in national examination. So that is why students should have good competence in English.

English its self has four basic skills and language components then vocabulary plays the important role in English Language Teaching. Moreover, vocabulary is the basic element of language which will make language meaningful. According to Khooi and Sharififar (2013), "Vocabulary is a core element of languageproficiency that provides major basis for learners' effective communication". English language teaching cannot be separated from learning its vocabulary because, thelanguage consists of many vocabularies which compose into complete sentence and becomes a language used in communication. An educated vocabulary learner will probably have around 20.000 of word families (Thornbury, 2002, P.20). 
Based on national educational system in Indonesia, English language teaching has been contained in the syllabus (curriculum) in junior high level to senior high level. In general, as stated in Syllabus Curriculum (Kurtilas Revision), "English language competence at SMA/MA and SMK/MK that students are able to communicate in three kind of text, [1] interpersonal, [2] transactional and [3] functional in written and spoken context."(Kemendikbud, 2016).However, those aspects are not really happened in reality. We can see many problems still exist in English learning, such as in reading, listening and writingalso in vocabulary.

According to The Ministry of Educational and Culture (2017), score in National Examination (UN) in 2017 specially in English subject has decreased from 48.66 to 47,43 or has decreased to 1,23 point (The Ministry of Educational and Culture, 2017). Then, the data above shows that students' ability in English language is still poor. In National Examination test many question items are mainly based on the comprehension of the text, then students must read the text and understand the meaning of words before they answer the question. However, most of students still difficult to understand the meaning of words it is caused by the students' vocabulary knowledge are not large enough.Then, the data below shows that students' ability in English language is still poor.

In addition, there are several factors which make students' vocabulary knowledge is not large enough one of them is inappropriate strategy usage. According to Brown (2001) "The teacher who always uses the conventional method to teach English subject and it also makes the students feel more bored to study English.” (p.75). Teaching vocabulary for senior high school needs appropriate and different strategy from traditional way. There are many strategies to teach vocabulary, one of appropriate strategies which can fulfill these requirements is semantic mapping. In teaching vocabulary, semantic mapping can be used as a tool for students to discover the relationships between vocabulary words (Gaut, 2002).

Moreover, this is also supported by previous relevant research. One of them studied byAbdelrahman(2013),Semantic mapping has great impact on students' vocabulary knowledge because it can motivate them to create lexical network among word. Khoii and Sharififar (2013), revealed that semantic mapping is a visual strategy for vocabulary expansion and extension of knowledge by displaying in categories related to another words. They also revealed semantic mapping have two aspects in teaching and learning language, they are visual and conceptual. In teaching vocabulary, it can be used as a tool for students to discover the relationships between vocabulary words.

Based on the study mentioned above, it motivated the researcher to analyze about students' performance in vocabulary knowledge in the same area by the usefulness and benefit of the use of semantic mapping as a strategy in vocabulary learning result. So that, the researcher decided to conduct this study about "Analyzing the Effect of Semantic Mapping Strategy on Students' Vocabulary Learning Result at the Grade Ten of SMK PUSAKA 1 Jakarta in Academic Year of 2017/2018".

\section{Methodology}

\section{Hypothesis}

To find out whether or not there is significant effect of using Semantic Mapping Strategy on Students' Vocabulary Learning Result, the hypotheses are formulated as follows: 


\section{Null Hypothesis (Ho)}

There is noeffect of using Semantic Mapping Strategy on Students' Vocabulary Learning Result at the Grade Ten of SMK Pusaka 1 Jakarta in Academic Year of 2017/2018.

\section{Alternative Hypothesis (Ha)}

There is significant effect of using Semantic Mapping Strategy on Students' Vocabulary Learning Result at the Grade Ten of SMK Pusaka 1 Jakarta in Academic Year of $2017 / 2018$.

\section{Research Design}

In this research, the researcher used a true experimental method, in which the treatment condition did not allow a strict control. This design of this research was randomized post-test only control group design. The first group namely as experimental that received Semantic Mapping Strategy and another group namely as control group that did not receive Semantic Mapping Strategy. Both groups were given post-test.

\section{Participants}

The populations of this research are 144 students of Grade Ten in MM (MultiMedia) class at SMK PUSAKA 1 Jakarta in Academic Year of 2017/2018 and consisting of 4 classes.To determine the sample of this research, the writer used Cluster Random Sampling. The number of students that participated in this research is about 72 students divided into two classes consisting each of 36 students in X.MM-2 as experimental class and X.MM-1 as control class.

\section{Variables and Measures}

In this research, independent variable is Semantic Mapping Strategy. Dependent variable in this research is Vocabulary Learning Result. To measure students' vocabulary learning result, the writer took score from indicators of vocabulary learning result, as follows:

1. Students are able to categorize the right pronoun to complete the sentence.

2. Students are able to implement a definition word to other definition from underline word.

3. Students are able to analyze the form of verb category correctly in the sentence.

4. Students are able to identify synonym or antonym of the words.

5. Students are able to complete the incomplete sentence with the available word choices.

\section{Validity and Reliability}

The indicators of vocabulary learning result ability were developed to be instrument. The instrument was objective test with 60 items. Those items were analyzed its validity using Pearson Product Moment Correlation Coefficient, reliability using Alpha Cronbach formula, 
difficulty index and discrimination power to obtain good instrument using Microsoft Excel 2010. After the items have been analyzed, the good items that valid, reliable, satisfactory and medium were chosen to obtain good data. The question items were left 43 numbers. But it was only used 30 good question items to simplify the data analysis.

\section{Procedure}

Procedures of the research are:

1. Planning. Planning phase of this research is preparing and arranging the research design to get the research data. Before conducting the research, the writer formulates the hypothesis based on some related theories and design teaching plan using Metacognitive Strategy in teaching reading comprehension.

2. Collecting Data. The data were collected by giving post test to the students in experiment class and control class.

3. Data Analysis. The data collected from the sample classes were analyzed by using ANOVA after the pre-requisite analyses of normality and homogeneity have been fulfilled.

4. Reporting. The research finding is reported and written based on the formal frame of writing.

\section{Result}

The research data were analyzed descriptively and inferentially. The descriptive statistic can be seen on the following table:

Table 1

Descriptive Statistic

\begin{tabular}{|l|r|r|r|}
\hline \multicolumn{2}{|c|}{} & $\begin{array}{c}\text { Experimental } \\
\text { Class }\end{array}$ & \multicolumn{1}{c|}{ Control Class } \\
\hline \multirow{2}{*}{$\mathrm{N}$} & Missing & 36 & 36 \\
\cline { 2 - 4 } & Valid & 0 & 0 \\
\hline Mean & 76.64 & 67.83 \\
\hline Std. Error of Mean & 1.365 & 1.500 \\
\hline Median & 75.50 & 66.00 \\
\hline Mode & 80 & 60 \\
\hline Std. Deviation & 8.188 & 9.000 \\
\hline Variance & 67.037 & 81.000 \\
\hline Kurtosis & .232 & -.739 \\
\hline Std. Error of Kurtosis & .768 & .768 \\
\hline Range & 36 & 35 \\
\hline Minimum & 60 & 50 \\
\hline Maximum & 96 & 85 \\
\hline Sum & 2759 & 2442 \\
\hline
\end{tabular}


From the table above, Mean (Average Score) of Experimental Class was 76.64and Control Class was 67.83. In Experiment Class, the maximum score was 96 and the minimum score was 60 while in control class, the maximum score was only 85 and the minimum score was 50. It is indicated that students who received Semantic Mapping Strategy was higher than students who did not receive Semantic Mapping Strategy. After the data were analyzed descriptively, the data were analyzed inferentially using One-Way ANOVA. The data were tested its normality (Kolmogorov Smirnov) and its homogeneity (Levene) as pre-requisite data analysis. The result of data analysis is presented as follows:

Table 2

ANOVA

\begin{tabular}{|l|c|c|c|c|c|}
\hline & Sum of Squares & Df & Mean Square & F & Sig. \\
\hline Between Groups & 437.871 & 1 & 437.871 & $\mathbf{7 . 8 0 1}$ & $\mathbf{. 0 0 9}$ \\
\hline Within Groups & 1908.435 & 34 & 56.130 & & \\
\hline Total & 2346.306 & 35 & & & \\
\hline
\end{tabular}

The calculation showed that the significant value (sig) is 0.009 . The significant value

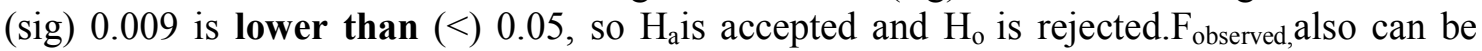
used to find out whether there is or nosignificant effect of variable $\mathrm{X}$ on $\mathrm{Y}$ through comparing with $\mathrm{F}_{\text {table. }}$ To find out $\mathrm{F}_{\text {table, }}$, the researcher used degree of freedom $(\mathrm{df})(1 ; 70)$, namely (3.98). The data showed that $F_{\text {observed }}$ value 7.801 is higher than $(>) F_{\text {table }}$ 3.98. From the data above it can be concluded that there is significant effect of variable $\mathrm{X}$ (Semantic Mapping Strategy) on variable Y (Vocabulary Learning Result).

\section{Discussion}

This research was designed to examine the effect of Semantic Mapping Strategy on students' Vocabulary Learning Result.This research empirically to prove is there effect of using Semantic Mapping Strategy on Students' Vocabulary Learning Result (significance value $<0.05(0.009<0.05))$. It can be seen from the differences between the result of the Control Class and Experimental Class. The Experimental Class which carried out learning strategy by using Semantic Mapping Strategy and the Control Class that carried out by using conventional strategy in vocabulary learning. By joining some theories about semantic mapping which can be used as a strategy in teaching vocabulary. According to Takac (2008), "Semantic mapping generally refers to brainstorming association which a word has and then diagraming the result." (p.22). Then, Gaut (2002) stated, "Semantic mapping is a technique that can be used in all disciplines to demonstrate the relationships between ideas." The use of semantic mapping can be used as a tool for students to discover the relationship between words and it will increase students vocabulary learning result.

Moreover, this finding is verified from the research finding which was conducted by the previous researches. First, research conducted by Dilek and Yuruk (2012). The result of study revealed that semantic mapping strategy can improve students' vocabulary knowledge through this study. In addition, the use of semantic mapping strategy was more effective and motivating them than conventional teaching strategy. Also, from this research semantic mapping has been found as an effective strategy for learning target vocabulary. Second, research conducted by Abdelrahman (2013), the study revealed that student can be active in 
the class when teacher using semantic mapping as a strategy in learning vocabulary. It is proved from the result of students' post-test students in experimental class had high score than students in control class. The last, another research conducted by Zahedi and Abdi (2012), the result of this study showed that student easier to understand the words by using semantic mapping as a teaching strategy. Referring to these researches the result of the research is not different. Furthermore, from previous researches and this research have similar in result of study that there is significant effect of semantic mapping in vocabulary learning result. By referring research finding form previous relevant researches, this research has the same condition in doing the research that semantic mapping strategy was more effective strategy on student vocabulary learning result.

In this research, the researcher found many condition when the researcher applied observation in both experimental class and control class. One of them is students' vocabulary knowledge. The students' vocabulary is not large enough yet in both classes in early meeting. But, when experimental was treated by using semantic mapping strategy students' vocabulary knowledge was increase. This is caused by the use of semantic mapping strategy many students became active because they learnt how to make many words from one word by drawing some diagram and related them. In contrast, this did not happen in control class, because they were not taught with semantic mapping.

In the real condition, most of students were happier when teacher taught in the class by using interesting strategy. It was happened with students in experimental class because they studied by using semantic mapping strategy. By this strategy student were stimulated to more active and work as a team. The implementation of this strategy made them to drawing some maps to discover the relationship among the words.Even though, the use of semantic mapping strategy helps students to be active and creative the researcher still found some problem in applying semantic mapping strategy. One of them is students' vocabulary knowledge, many students have not large enough in vocabulary knowledge. It is caused they difficult to find out the relationship among words. In conclusion, the use of semantic mapping strategy gave significant effect on students' vocabulary learning result. It is caused semantic mapping strategy helps the students learn new words and its relationship among the words.

\section{Conclusion}

The application of semantic mapping on students' vocabulary learning result has successfully finished. The result of this research has passed stage of data testing such as normality, homogeneity and One Way ANOVA test. By referring the research finding, the researcher concluded that there is effect of semantic mapping strategy on students' vocabulary learning result at the grade ten of SMK Pusaka 1 Jakarta in academic year of 2017/2018. The effect can be seen from the improvement on students' vocabulary learning result through post-test result.Applying semantic mapping strategy in the class has many benefits effect. First, it makes students active in the class. Second, it makes students become interest in learning English especially in learning vocabulary. And the last, the use of semantic mapping strategy help students to enhance their vocabulary learning result.

Even, the use of semantic mapping strategy has many benefits effect on students' vocabulary learning result some problem was found in the process of research implementation. They were the lack of students' vocabulary knowledge. By facing this problem the teacher should be patient to guide them and give more some clue world to make 
them understand.By referring this research which has been fully applied, it is suggested English teacher should use Semantic Mapping Strategy in teaching vocabulary. It will motivate students to be creative in the class because they will learn many words by drawing some maps. The school also has to provide the appropriate facilities that support the teaching and learning processin order that the learning objectives can be achieved.

\section{REFERENCES}

Abdelrahman, O. M. (2013, July). The Effect of Teaching Vocabulary through Semantic Mapping on EFL Learners' Awareness of Vocabulary Knowledge at Al Imam Mohammed Ibin Saud Islamic University. International Interdisciplinary Journal of Education, II(7), 722-731.

Abdulrahman, T. R. (2016). Edmodo as a Supplementary Teaching in EAP Classroom: Perception and Reality. The Bandung International Conference on Language and Education (pp. 39-50). Bandung: Institut Teknologi Bandung.

Abdulrahman, T. (2016). TED Talks as Listening Teaching Strategy in EAP Classroom. The Asian EFL Journal Second Language Acquisition - Academic Research, 72-93.

Amminuddin. (2001). Semantik : Pengantar Studi Tentang Makna. Malang: Sinar Baru Algensindo.

Anderson; Krathwohl;. (2001). A Taxonomy for Learning, Teaching, and Assessing: A Revision of Bloom's Taxonomy of Educational Objectives. Now York: Longman.

Arikunto, S. (2010). Prosedur Penelitia Suatu Pendekatan Praktik Edisi Revisi. Jakarta: Rineke Cipta.

Basri, H. (2013). Landasan Pendidikan. Bandung: CV Pusaka Setia.

Bauer, L. (2001). Vocabulary : Language Workbooks. (R. Hudson, Ed.) London: Routledge.

Brown, H. D. (2001). Teaching by Principle : An Interactive Approach to Language Pedegogy. New York: Addison Wesley Longman Inc.

Dilek, Yesim; Yuruk, Nurcihan. (2012). Using Semantic Mapping Technique in Vocabulary Teaching at Pre-intermediate Level. Procedia - Social and Behavioral Sciences(70), $1531-1544$.

Dimyati; Mudjiono;. (2009). Belajar dan Pembelajaran. Jakarta: Rineka Cipta.

Flanigan, Kevin; Greenwood, Scott C;. (2007). Effective Content Vocabulary Instruction in The Middle : Matching Students, Purposes, Words and Strategies. Iinternational Reading Association, 226-238. doi:101598

Gaut, R. (2002). Semantic Mapping Technique. New York: Prentice Hall.

Huyen. (2003). Learning Vocabulary through Games: The Effectiveness of Learning Vocabulary through Games. Asian EFL Journal. Retrieved from http:/www.asian-efljournal.com. 
Johnson, Burke; Chritensen, Larry;. (2008). Educational Research : Quantitative, Qualitative and Mix Approaches Third Edition. California, United States of America: Sage Publication, Inc.

Kaufhold, J. A. (2002). The Psychology of Learning and The Art of Teaching . New York: Writers Club Press.

Kementrian Pendidikan dan Kebudayaan RI. (2016). Silabus Mata Pelajaran. Silabus Mata Pelajaran Bahasa Inggris SMA/MA/SMK/MAK.

Kementrian Pendidikan dan Kebudayaan RI. (2017). Hasil Ujian Nasional. Retrieved from Puspendik: http://puspendik.kemdikbud.go.id/hasil-un/

Khoii, R; Sharififar, S;. (2013). Memorization versus semantic in second language vocabulary acquisition. $\operatorname{ELT}(2), 67$.

Kothari, C. R. (2004). Research Methodology: Methods and Techniques. 2nd Edition. New Delhi: New Age International Publishers.

Kreidler, C. W. (2002). Introducing English Semantic. New York: the Taylor \& Francis eLibrary.

Nation, I. S. (2000). Learning Vocabulary in Another Language.

Nickols, F. (2016). Strategy: Definition and Meaning. 1-13.

Nisfiannoor, M. (2009). Pendekatan Statistika Moderen untuk Ilmu Sosial. (A. N. Dini, Ed.) Jakarta: Salemba Humanika.

Norbert, S. (2000). Vocabulary in English Teaching. Cambridge: Cambridge University.

Rather, A. R. (2004). Psychology of Learning and Development . New Delhi: Discovery Publishing House.

Santoso, S. (2010). Statistik Multivariat : Konsep dan Aplikasi dengan SPSS. Jakarta: PT. Elex Media Komputindo.

Sudjana, N. (2010). Penilaian Hasil Proses Belajar Mengajar. Bandung: PT. Remaja Rosdakarya.

Sugiyono. (2010). Statistika Untuk Penelitian. Bandung: CV. Alfabeta.

Sugiyono. (2011). Metode Penelitian Pendidikan Pendekatan Kuantitatif, Kualitatif dan $R \& D$. Bandung: Alfabeta.

Takac, V. P. (2008). Vocabulary Learning Strategies and Foreign Language Acquisition. Dublin: the Cromwell Press Ltd.

Thornbury, S. (2002). How to Teach Vocabulary. London: Longman.

Zahedi, Yagoub; Abdi, Mortaza;. (2012). The Effect of Semantic Mapping Strategy on EFL Learners' Vocabulary Learning. International Conference on Education and Educational Psychology(69), 2273-2280. 